\title{
THE ANALYSIS OF DIMENSIONAL STABILITY OF 1X1 RIB COTTON KNITTWEAR
}

\author{
Marija Pešić*, Vasilije Petrović, Danka Joksimović, Anita Milosavljević
}

(ORIGINAL SCIENTIFIC PAPER) UDC 677.075:677.072:677.21

Technical faculty "Mihajlo Pupin", University of Novi Sad, Zrenjanin, Serbia

This paper analyzes the impact of the yarn linear density used in the dimensional stability of the 1X1 RIB knitwear made on the same circular knitting machine. The used samples of raw knitwear are made from $100 \%$ cotton yarn with different liner densities of $19,17,15$ and 13 tex. Dimensional stability of these samples was analyzed by FAST 4. The results show that the most stable knitwear is made of $100 \%$ cotton yarn with the linear density 19 tex. The values of the tightness factor in the dry relaxation stood at 14, 93,15, 14under wet,16,32 under total and 16,20 under air conditioned conditions. The knitwear with the highest values of dimensional instability is a raw knitted fabric made of $100 \% \mathrm{CO}$, and the yarn with the linear density of 13 tex. The values of the tightness factor in the dry relaxation stood at 16,20 under wet, 15,14 under total and 12,53 under air conditioned conditions.
Keywords: $1 \times 1$ rib cotton knitwear, knitwear dimensional stability, dimensional constants, the tightness factor

\section{Introduction}

One of the most important indicators of knitted products is their dimensional stability. Knitted fabrics have a structure which offers a stretch ability and the elasticity of knitwear. These advantages make knitwear comfortable and fit well to body contours, providing transpiration as well[1].

In the yarn which has formed a loop, a certain amount of potential energy is accumulated. This energy causes a certain pressure yarn against yarn in places where these yarns intersect in knitwear. In these places, frictional forces appear between the yarns and prevent their displacement. The yarn tends to get rid of deformations that have occurred in the shaping of the loop which causes shrinkage of knitwear. The knitwear shrinkage stops when these deformation and friction forces are in balance[2].

The impact of the raw material is significant for dimensional stability, i.e. the fiber type, the shape, intersection and linear density of fibers, a spinning process, a linear density of the yarn, a type and number of twists of the yarn. The fiber characteristics significantly influence the knitting [2].

The impact of the water treatment is also significant. During the penetration into intermicellar spaces in cellulose fibers, water molecules lead to swelling of fibers and as a result the yarn diameter in the loop increases by 20 to $30 \%$ [3]. Wet processing is usually accompanied by the increase of the temperature of processing agents. The result is the increase of the yarn thickness, to which shape of the loop need to adapt [4]. All this leads to knitwear shrinkage.

When designing clothing products a big issue is the prediction of the dimensional stability of knitwear. This problem is expressed during the exploitation of knitted products, as well as during their washing, because very often there are significant dimensional changes in clothing products that reduce their quality[3].

The purpose of this paper is collecting relevant information in the form of the dimensional stability of knitwear in order to obtain the results that will make future clothes projecting easier in order to fulfill the customer demands.

\section{Experimental}

The experimental part of this paper analyses the dimensional stability of the $1 \times 1$ RIB knitwear made of $100 \%$ CO yarns used in four linear densities: 19, 17,15 and 13 tex.Raw state samples were examined (Table 1).

Table 1. Basic characteristics of the analyzed knitwear samples

\begin{tabular}{ccccc}
\hline Samples & $\mathrm{C} 1$ & $\mathrm{C} 2$ & $\mathrm{C} 3$ & $\mathrm{C} 4$ \\
\hline Structure & $1 \times 1 \mathrm{RIB}$ & $1 \times 1 \mathrm{RIB}$ & $1 \times 1 \mathrm{RIB}$ & $1 \times 1 \mathrm{RIB}$ \\
Fiber composition & $100 \% \mathrm{CO}$ & $100 \% \mathrm{CO}$ & $100 \% \mathrm{CO}$ & $100 \% \mathrm{CO}$ \\
Linear density (tex) & 19 & 17 & 15 & 13 \\
Twists $\left(\mathrm{m}^{-1}\right)$ & 565 & 627 & 655 & $693 /-$ \\
Finishing & raw & Raw & raw & raw \\
\hline
\end{tabular}

Knitwear is made on a circular knitting machine type $\mathrm{Fv}$ 2.0 of company Mayer \& Cie. The characteristics of the machine are as follows: cylinder diameter 19 "(inch), the gauge is E18 and with 40 feeders, the knitting speed is $1.7 \mathrm{~m} / \mathrm{s}$. All of the samples are knitted under the same conditions on the same machine.

The dimensional stability of the samples was analyzed by the FAST 4 method. The measurement was performed on

\footnotetext{
*Author address: Marija Pešić, Technical faculty "Mihajlo Pupin", Djure Djakovića bb, 23000 Zrenjanin , Serbia

E-mail: marija.stankovic.986@gmail.com

The manuscript received: September, 11, 2018.

Paper accepted: October, 24, 2018.
} 
20 samples of the same type and in the measurement result that follows, the arithmetic mean values of these 20 samples is represented.

Determination of the dimensional stability by the FAST 4 method

Dimensions of the sample were $300 \times 300 \mathrm{~mm}$. The samples with the $5 \mathrm{~cm}$ minimum distance from the edges of the knitwear were taken. The FAST 4 method has several stages [5]. First, the conditioned samples of the knitwear has to be exposed to heat at the temperature of $105^{\circ} \mathrm{C}$ in a dryer for the period of $60 \mathrm{~min}$, after which the dimensions of the samples have to be taken in the longitudinal and transverse direction for a period of 30 seconds (length L1) (Dry relaxation $\mathrm{S}$ ). This is followed by immersion of a dry sample in water for 30 minutes, at the temperature of $25^{\circ} \mathrm{C}$ to $30^{\circ} \mathrm{C}$ with the addition of $0.1 \%$ detergent. After that, the sample has to be placed on a smooth surface with gentle pressing in order to remove the excess water, after which the sample should be measured again (length L2) (Wet relaxation $\mathrm{W})$. The sample is then returned to the dryer to be exposed to heat at the temperature of $105{ }^{\circ} \mathrm{C}$ for $60 \mathrm{~min}$. The dried sample is measured over a period of 30 seconds to obtain the length L3 (Full relaxation F). At the end, the sample is left for relaxation, and after conditioning in a room with standard atmospheric conditions according to ISO 139, the sample is measured (length L4) (Climatization - C) (Figure 1).

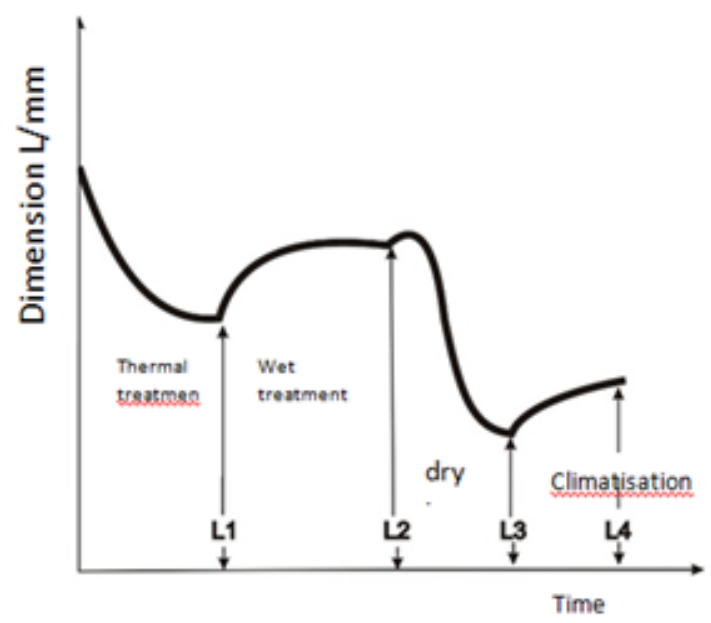

Figure 1. Diagram of the flow test of dimensional stability by fast 4 methods

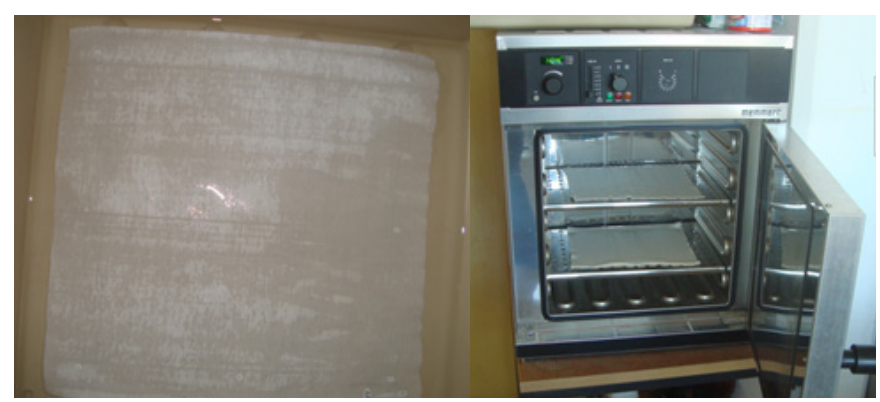

Figure 2. a) knitwear sample in water bath, b) knitwear sample in drying machine FAST 4
According to the method FAST 4, relaxing shrinkage is defined as percentage change of the dimension of the knitwear sample after the heat and wet processing. It can be described as the ratio of the difference between the dry sample length after the heat treatment (length L1) and the dimension of the dried sample after relaxation at the wet state (length L3) and the dimension of the dry sample after the heat treatment (length L1). Relaxation shrinkage of the knitwear sample can be represented by the following expression 1 [6]:

$R S=\frac{L_{1}-L_{3}}{L_{1}} \cdot 100[\%]$

FAST 4 method defines relaxing stretching in a wet condition as the percentage change of the dimension of the knitwear sample upon the wet treatment, and is calculated according to the following expression 2[6]:

$H E=\frac{L_{2}-L_{3}}{L_{2}} \cdot 100[\%]$

\section{Results and discusion}

In Figures 3 and 4, we can see that raw samples of knitwear made from finer yarns have more shrinkage of the knitwear which are made of the coarser and stronger yarn.

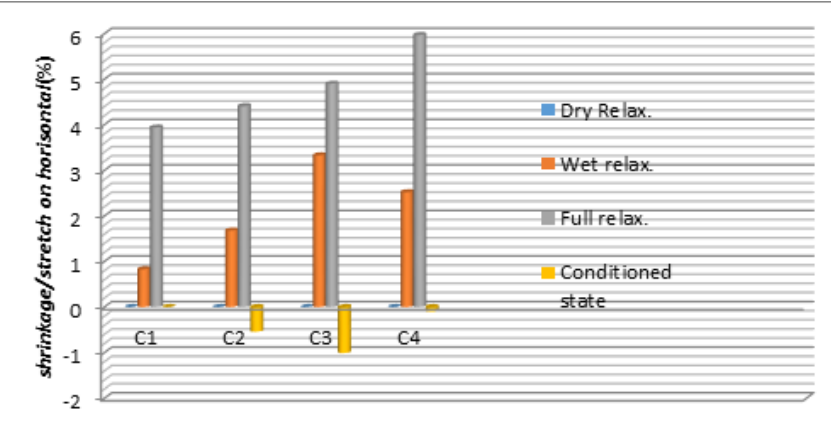

Figure 3. shows the same values but measured on vertical axis of knitted samples.

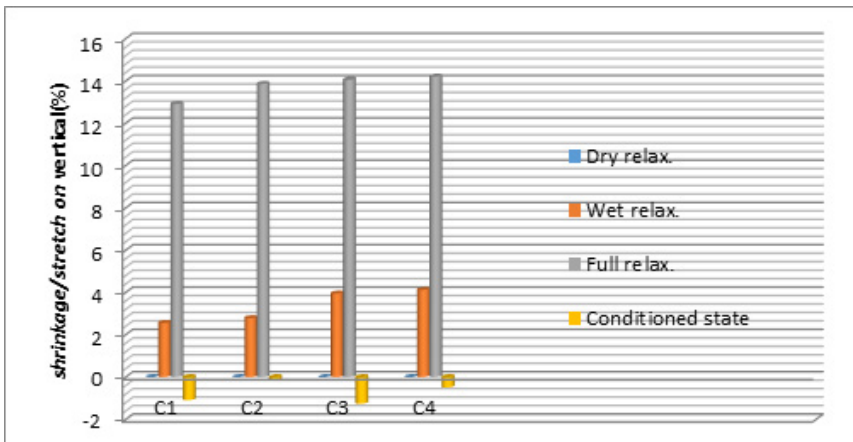

Figure 4. shows the same values but measured on horizontal axis of knitted samples.

Dimensional constants K-values

In order to monitor the stability of the knitted structure through different states of relaxation, dimensional 
constants can be used. Usually, the following Munden's geometrical correlations are used [1] for calculating the dimensional constants of the knitwear 4 relaxation conditions: $\quad K_{c}=\frac{D h}{l} ; K_{w}=\frac{D_{v}}{l} ; K_{r}=\frac{K_{c}}{K_{w}} ; K_{s}=S \cdot I^{2}$

I- the mean value of the yarn length in a loop,

$K c, K w, K r a n d ~ K s$-dimensional constants, S - the loop density, Dh - number of loops in horizontal, Dv- number of loops in vertical, I - yarn lenght, .

$\mathrm{K}$ values are important for the prediction of structural behavior, for creating a material with better stability and for determining the minimum / lower energy level of loops after treatment. $\mathrm{K}$ constants can interconnect the values $\mathrm{Dh}, \mathrm{Dv}$ and the yarn length in a loop. $K w$ and $K c$ are constants of $\mathrm{Dv}$ and $\mathrm{Dh}$. Kr constant represents the ratio of the constants $K c / K w$. This is a direct measure of the shape and it is called the shape factor of the loop. $K s$ is a constant overall density of loops. It is the product constants $K c$ and $K w$ [1]. Table 2 shows the value of dimensional constants for the test samples.

Table 2. Values of dimensional constants for samples

\begin{tabular}{cccccc}
\hline & & C1 & C2 & C3 & C4 \\
\hline I & Cm & $0.280 \pm 0.0111$ & $0.292 \pm 0.005$ & $0.293 \pm 0.0121$ & $0.269 \pm 0.0063$ \\
D & $4.06 \pm 0.0581$ & $3.81 \pm 0.0122$ & $3.76 \pm 0.0456$ & $3.68 \pm 0.0107$ \\
W & $4.19 \pm 0.0465$ & $3.87 \pm 0.0185$ & $3.95 \pm 0.0479$ & $3.77 \pm 0.0239$ \\
F & $4.27 \pm 0.0475$ & $4.00 \pm 0.0191$ & $4.05 \pm 0.0490$ & $3.80 \pm 0.0241$ \\
C & $4.19 \pm 0.0466$ & $3.97 \pm 0.0189$ & $4.02 \pm 0.0487$ & $3.73 \pm 0.0237$ \\
D & $6.30 \pm 0.0901$ & $6.46 \pm 0.0207$ & $6.62 \pm 0.0801$ & $6.84 \pm 0.0200$ \\
W & $6.34 \pm 0.0704$ & $6.53 \pm 0.0312$ & $6.70 \pm 0.0811$ & $8.14 \pm 0.0516$ \\
F & $6.55 \pm 0.0727$ & $6.68 \pm 0.0319$ & $6.73 \pm 0.0815$ & $7.92 \pm 0.0502$ \\
C & $6.52 \pm 0.0724$ & $6.61 \pm 0.0315$ & $6.71 \pm 0.0813$ & $7.91 \pm 0.0501$ \\
D & $1.55 \pm 0.0222$ & $1.70 \pm 0.0054$ & $1.76 \pm 0.0213$ & $1.86 \pm 0.0054$ \\
W & $1.51 \pm 0.0168$ & $1.69 \pm 0.0081$ & $1.70 \pm 0.0205$ & $2.16 \pm 0.00137$ \\
F & $1.53 \pm 0.0170$ & $1.67 \pm 0.0080$ & $1.66 \pm 0.0202$ & $2.08 \pm 0.0132$ \\
C & $1.55 \pm 0.0173$ & $1.67 \pm 0.0080$ & $1.67 \pm 0.0202$ & $2.12 \pm 0.0134$ \\
D & $25.58 \pm 0.3658$ & $24.65 \pm 0.0789$ & $24.89 \pm 0.3014$ & $25.20 \pm 0.0735$ \\
W & $26.54 \pm 0.2949$ & $25.30 \pm 0.1207$ & $26.49 \pm 0.3207$ & $30.69 \pm 0.1945$ \\
F & $27.98 \pm 0.3108$ & $26.76 \pm 0.1276$ & $27.24 \pm 0.3299$ & $30.08 \pm 0.1907$ \\
C & $27.33 \pm 0.3036$ & $26.25 \pm 0.1252$ & $27.00 \pm 0.3270$ & $29.50 \pm 0.1871$
\end{tabular}

Legend: D - dry relaxation, W - wet relaxation, F- Full relaxation, C -conditioned sample, I - the mean value of the length of the yarn in a loop $(\mathrm{cm})$.

The results shown in Table 2 indicate that the values of dimensional constants increase with the increase of relaxation, except for the conditioned samples where the values decrease. The values of the constants rise with the knitwear which is made of thinner cotton yarns, comparing with the ones made of thicker cotton yarns.

Also, with the change of the relaxation condition, it can be seen that $\mathrm{Kr}$ constant or a loop shape factor is significantly reduced as a result of achieving a stable condition.With the increase of relaxation, the minimum energy is produced so that the loop cannot be changed further and occupies the envisaged state in the space.

In Figures 5 to 8 , the change in $\mathrm{K}$ is shown graphi- cally in relation to the length of the yarn in the loop.

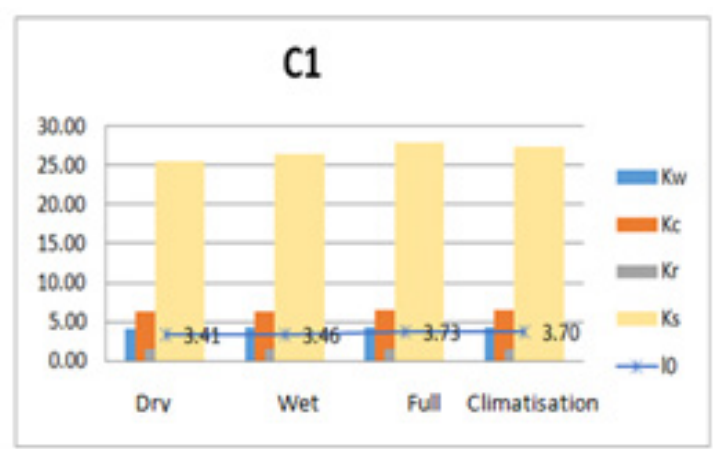

Figure 5. Changes in $\mathrm{K}$ in relation to the yarn length in a loop $\left(\mathrm{I}_{0}\right)$ for sample C1

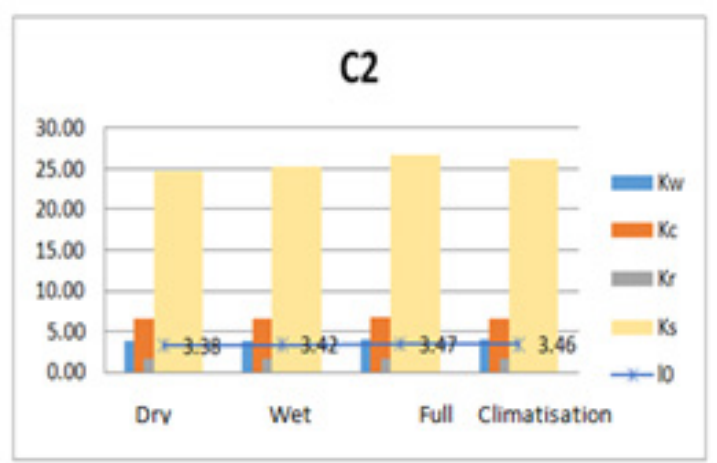

Figure 6. Changes in $\mathrm{K}$ in relation to the yarn length in a loop $\left(\mathrm{I}_{0}\right)$ for sample C2

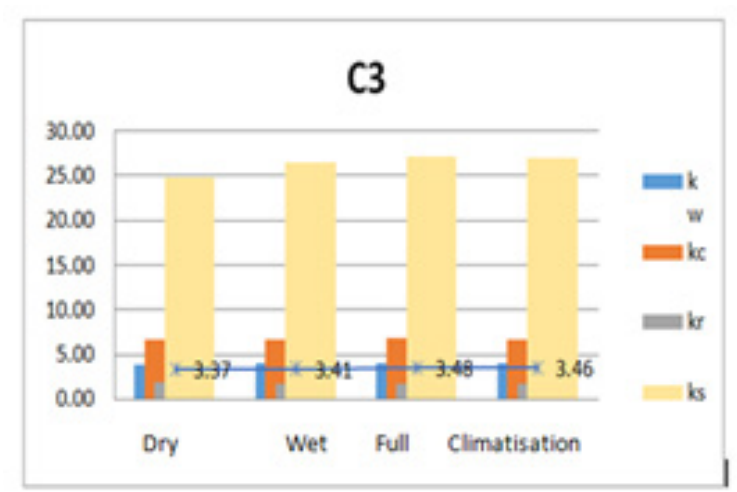

Figure 7. Changes in $\mathrm{K}$ in relation to the yarn length in a loop $\left(\mathrm{I}_{0}\right)$ yarn for sample $\mathrm{C} 2$

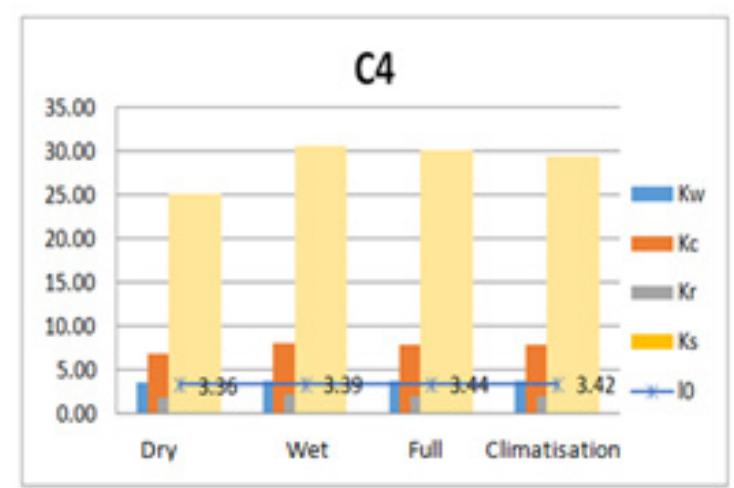

Figure 8. Changes in $\mathrm{K}$ in relation to the yarn length in a loop $\left(I_{0}\right)$ for sample C3 
Tightness factor variations

Tightness factor represents a measure of the knitwear density and it can be calculated by the following equation 3 [1]:

Tigtnessfactor $(T F)=\frac{\sqrt{t e x}}{l} ;\left(\right.$ tex $\left.^{1 / 2} \mathrm{~cm}^{-1}\right)$.

or it can be represented as:[1]:

Structural tightness factor $(\mathrm{STF})=T S \cdot K S\left(\operatorname{tex}^{1 / 2} \mathrm{Cm}^{-1}\right) \ldots(4)$

where:TF - Tightness factor, te $\mathrm{x}^{1 / 2} \mathrm{~cm}^{-1} ; \mathrm{Tt}$ - linear density, tex; I - yarn's length in a loop, $\mathrm{cm}$.

Table 3. Values of the tightness factor for the measured samples

\begin{tabular}{ccccccccc}
\hline & \multicolumn{3}{c}{ TF } & \multicolumn{5}{c}{ STF } \\
& D & W & F & C & D & W & F & C \\
\hline C1 & 14.93 & 15.14 & 16.32 & 16.20 & 381.97 & 299.05 & 341.77 & 329.72 \\
C2 & 14.78 & 14.98 & 15.19 & 15.14 & 364.39 & 379.10 & 406.47 & 397.31 \\
C3 & 12.32 & 12.49 & 12.75 & 12.66 & 306.66 & 330.78 & 347.37 & 341.92 \\
C4 & 12.28 & 12.40 & 12.57 & 12.53 & 309.40 & 380.62 & 378.30 & 396.72 \\
\hline
\end{tabular}

Table 3 shows that the value of the TF decreases from full, through wet to dry relaxation. It shows that thicker knitwear provides a greater value of TF comparing with the knitwear made of the thinner yarn.

Mathematical model for describing the relation between TF and the value of the yarn's length $\left(I_{0}\right)$ in the knitwear loop

To determine TF dependencies from the length of theyarn in the knitwear loop, a specific mathematical model is introduced. In order to represent the method of nonlinear regression, a polynomial model is used.

For a given set of data pairs $\left(x_{1}, y_{1}\right),\left(x_{2}, y_{2}\right), \ldots,\left(x_{n}, y_{n}\right)$ the following relation should be found, $y=a_{0}+a_{1} x+\ldots+a_{m} x^{m}$, whereby $m \leq n-2$, so experimental data can be best represented.

The results of the experimental research have been approximated by a non-linear model fitting data which has a form of polynomial of degree 4:

$T F=a_{0}+a_{1} \cdot I_{0}+a_{2} \cdot I_{0}^{2}+a_{3} \cdot I_{0}^{3}+a_{4} \cdot I_{0}^{4}$

where $\mathrm{a} 0, \mathrm{a} 1, \mathrm{a} 2, \mathrm{a} 3, \mathrm{a} 4$ are constants, $\mathrm{I}_{0}$ independent variable i.e. the length of the yarn in the loop twists. As $\mathrm{I}_{0}$ in knitwear changes depending on relaxation, the TF value changes according to the previous formula. Table 4 gives an overview of calculated coefficients of the empirical formula for the TF value changes depending on the length of the yarn in the loop.
Table 4. Overview of calculated coefficients of the empirical formula for TF changes depending on the $\mathrm{I}_{0}$

\begin{tabular}{cccccc}
\hline & \multicolumn{5}{c}{ Coefficients TF } \\
Sample & a0 & a1 & a2 & $a_{3}$ & $a_{4}$ \\
\hline C1 & 81.92 & -570.21 & 2011.48 & -3538.55 & 2533.35 \\
C2 & 71.49 & -482.65 & 1654.8 & -2833.57 & 1940.8 \\
C3 & 65.91 & -451.05 & 1538.51 & -2625.48 & 1792.16 \\
C4 & 67.61 & -498.7 & 1849.46 & -3437.64 & 2555.89 \\
\hline
\end{tabular}

\section{Conclusion}

This paper analyzes the impact of linear density of the yarn for raw cotton 1X1 RIB knitwear, made on the same circular knitting machines by using the FAST method. The results obtained show that the most stable knitwear is made of $100 \%$ cotton with the yarn fineness 19 tex. The values of the tightness factor in the dry relaxation stood at 14,93, in wet 15,14, in total 16,32 and 16,20 under air conditioned conditions. The knitwear with the highest values of dimensional instability is raw knitwear made of $100 \% \mathrm{CO}$, and the yarn with the linear density of 13 tex. The values of the tightness factor in the dry relaxation stood at 16,20, in wet 15,14, in total 12,66 and 12,53 under air conditioned conditions.

Also, the impact of the length of the yarn in the loop on the dimensional stability of the knitwear during dry, wet and complete relaxation, and relaxed samples in the conditioning chambers after the treatments were analyzed in the paper. It was noted that the differences in the length of the yarn in the loop linearly related to the length of the yarn in the loop at different stages of relaxation.

It can be also concluded that values $K c$ and $K w$ increase in the knitwear which is made of the thinner yarn. $K r$ decreases with the increase of relaxation which means that the loop reaches its stable state and it has a minimal ability to change the shape. Ks factor rises significantly with the increase of relaxation and with the increase of the TF.

In complete relaxation, all samples recorded the largest dimensional change and for sample $\mathrm{C} 1$ the shrinkage on vertical is 12.91 , and on horizontal $3,94 \%$, while $\mathrm{Kr}$ is in dry relaxation $1.55 \pm 0.0222$, in wet relaxation $1.51 \pm 0.0168$, and in full relaxation $1.53 \pm 0.0170$. The amount of $K s$ factor in dry relaxation is $25.58 \pm 0.3658$, in wet $26.54 \pm 0.2949$, in full $27.98 \pm 0.3108$. The most instable knitwear is sample $\mathrm{C} 4$ and here the vertical shrinkage is in the amount of $14,21 \%$, horizontal shrinkage is $5,97 \%$, while $K r$ in dry relaxation is $1.86 \pm 0.0054$, in wet $2.16 \pm 0.0137$, in full $2.08 \pm 0.0132$, Ks factor in dry relaxationis $25.20 \pm 0.0735$, in wet $30.69 \pm 0.1945$ and in full $30.08 \pm 0.1907$. 


\section{Acknowledgements}

This work is part of the research project "The development of new and the improvement of the existing technological processes for the production of technical textile materials", br. TR 34020, funded by the Ministry of Education, Science and Technological Development of the Republic of Serbia.

\section{References}

[1] Edin Fatkić, Jelka Geršak, Darko Ujević, Influence of knitting parameters on the mechanical properties of plain jersey weft knitting fabric, Fibres and textiles in Eastern Europe, vol 19 (2011)87-97:

[2] Antônio Augusto Ulson de Souza, Luiz Felipe Cabral Cherem and Selene M. A. Guelli U. Souza, Prediction of Dimensional Changes in Circular Knitted CO Fabrics, Textile Research Journal, Vol 80(3): (2011)236-252,

[3] Chathura N. Herath and Bok Choon Kang, Dimensional Stability of Core Spun CO/Spandex Single Jersey Fabrics under Relaxation, Textile Research Journal, Vol 78(3) (2008)209-216

[4] Munden, D. L., The Geometry and Dimensional Properties of Single Jersey-Knit Fabrics, Textile Research Journal, Vol 50(1959) T448-T471

[5] J. Gersak, Objektivnovrednovanjeplošnihtekstilija i odjeće, Faculty of Textile Technology, Zagreb (2014)

[6] V. Petrovic, Tehnologijapletenja, Tehnickifakultet "Mihajlo Pupin", Zrenjanin, Serbia (2000)

[7] A. Bayazit Marmarali, Dimensional and Physical Properties of CO/Spandex Single Jersey Fabrics, Textile Research Journal, Vol73(2003) 11-14,

[8] S. C. Anand, K. S. M. Brown, L. G. Higgins, D. A. Holmes, M. E. Hall and D. Conrad, Effect of laundering on the dimensional stability and distortion of knitted fabric, AUTEX Research Journal, Vol. 2 No2 (2002)85-100
[9] Knopten, J. J. F., Ahrens, F. J., Ingenthron, W. W., and Fong, W., The Dimensional Properties of Knitted Wool Fabrics, Part 1:the Single Jersey Structure, Textile Research Journal, Vol 38(1986)999-1012

[10] S. C. Anand, K. S. M. Brown, L. G. Higgins, D. A. Holmes, M. E. Hall and D. Conrad, Predicting fabric weight per unit area of single - and double knitted structures using appropriate software, AUTEX Research Journal, Vol. 6 No. 4 (2006)223-237

[11] Sandip Mukherjee, Sadhan Chandra Ray, S K Punj, Dimensional parameters of $1 \times 1$ rib fabric produced on a circular bed double jersey knitting machine using ultrasonic technique, Indian Journal of Fibre\&Textile Research, Vol 39(2014)230-237,

[12] C. Prakash, K. Thangamani, Establishing the effect of a loop lenght on dimensional stability of single jersey knitted fabric made from CO/LY core spun yarn, Indian Journal of Science and Technology, Vol 3, No 3(2010)287-289,

[13] D.T.Stojiljkovic, V.Petrovic, S.T.Stojiljkovic, D.Ujevic: Defining of memory function for tension and deformation of linear textile products on the basis of their rheological models, IndustriaTextila, No. 6, (2009); ISSN 1222-5347.

[14] J. Stepanovic, Z Milutinovic, V. Petrovic, M. Pavlovic Influence of relative density on deformation characteristics of fabrics in plain weave, Indian Journal of Fibre and Textile Research, No.1 Vol.34 (2009) 69-75

[15] D. Radivojevic, J. Stepanovic, M. Stamenkovic, V. Petrovic, Analysis of Deformation Charasteristics of Twisted Woolen Yarns, Tekstil, No 11(2008) 563-568

[16] D.T.Stojiljkovic, V.Petrovic, M.Dj-Petrovic: Rheological modelling of yarn extension, Tekstil, No.9 (2007) pp.554561

\section{Izvod \\ ANALIZA DIMENZIJSKE STABILNOSTI 1X1 REBRASTIH PAMUČNIH PLETENINA}

Marija Pešić, Vasilije Petrović, Danka Joksimović, Anita Milosavljević

Tehničkifakultet "Mihajlo Pupin", Univerzitet u NovomSadu, Zrenjanin, Srbija

$U$ radu je analiziran uticaj finoće pređe na dimenzijsku stabilnost $1 \times 1$ rebrastih pletenina izrađenih na istojkružnoj mašini za pletenje. Upotrebljeni uzorci sirovih pletenina izrađeni su od $100 \%$ pamučne pređe različitih finoća i to $19,17,15$ i 13 texa. Analiza je sprovedena metodom FAST 4..Dobijeni rezultati pokazuju da su najstabilnije pletenine izrađene od pređe finoće 19 tex-a. Vrednosti pokrivnog faktora u suvoj relaksaciji iznosile su 14,93, u mokroj 15,14, u potpunoj 16,32 i u klimatizovanim uslovima 16,20. Pletenine sa najvećim stepenom dimenzijske nestabilnosti su sirove pletenine od $100 \%$ pamuka, izrađene od pređefinoće 13 tex-a. Vrednosti pokrivnog faktora u suvoj relaksaciji iznosile su 16,20, u mokroj 15,14, u potpunoj 12,66 i u klimatizovanim uslovima 12,53.
(ORIGINALNI NAUČNI RAD) UDK 677.075:677.072:677.21

Ključne reči: : 1x1 rebrasta pamučna pletenina, dimenzijska stabilnost pletenina, dimenzijske konstante, pokrivni faktor 